\title{
Perilaku Konsumsi Pangan
}

\author{
Andi Nursiah ${ }^{1}$, Risma Haris ${ }^{2}$ \\ Fakultas Kesehatan Masyarakat, Universitas Islam Makassar, Sulawesi Selatan, Indonesia \\ Fakultas Kesehatan Masyarakat, Universitas Indonesia Timur, Sulawesi Selatan, Indonesia \\ arismarifin@gmail.com
}

(C) 2018 - UEJ Program Studi Pendidikan Kependudukan dan Lingkungan Hidup

Universitas Negeri Makassar. Ini adalah artikel dengan akses terbuka dibawah Licensi CC BY-NC-4.0 (http:/creativecommons.org/licenses/by-nc/4.0)

\begin{abstract}
.
Fungsi pangan yang utama bagi manusia adalah untuk memenuhi kebutuhan zat-zat gizi tubuh. bahan pangan sebaiknya juga memiliki fungsi sekunder (secondary function), yaitu memiliki tampilan dan cita rasa yang baik. Seiring dengan makin meningkatnya kesadaran masyarakat akan pentingnya hidup sehat, maka tuntutan konsumen terhadap bahan pangan juga kian bergeser. Tujuan Pembangunan Milenium (MDGs) mengintruksikan kepada pusat dan seluruh provisni untuk menyusun Rencana Aksi Pangan dan Gizi 20112015. Sehingga artikel ini merupakan kajian teori tentang perilaku konsumsi pangan yang membahas tentang teori perilaku, konsumsi dan pangan. Berdasarkan teori-teori yang telah disajikan, maka dapat disimpulkan bahwa Perilaku Konsumsi Pangan adalah polapola konsumsi terhadap ketersediaan pangan, daya beli terhadap pangan, pengetahuan, dan sikap terhadap yang berasal dari sumber hayati dan air, baik yang diolah maupun yang tidak diolah, yang diperuntukkan sebagai makanan ataupun minuman bagi konsumsi manusia.
\end{abstract}

Keyword; perilaku, konsumsi, pangan, masyarakat, gizi

\section{PENDAHULUAN}

Filosofi makan telah mengalami pergeseran, yang mana makan bukanlah sekedar untuk kenyang, melainkan yang lebih fokus utama adalah untuk mencapai tingkat kesehatan dan kebugaran yang optimal. Fungsi pangan yang utama bagi manusia adalah untuk memenuhi kebutuhan zat-zat gizi tubuh. Fungsi pangan yang demikian dikenal dengan istilah fungsi primer (primary function). Tidak hanya memiliki fungsi primer, bahan pangan sebaiknya juga memiliki fungsi sekunder (secondary function), yaitu memiliki tampilan dan cita rasa yang baik. Seiring dengan makin meningkatnya kesadaran masyarakat akan pentingnya hidup sehat, maka tuntutan konsumen terhadap bahan pangan juga kian bergeser.

Peraturan yang mengatur tentang Pola Pangan dan Gizi masyarakat antara lain UU Nomor 17 Tahun 2007 tentang Rencana Pembangunan Jangka Panjang (RPJPN) Tahun 2005-2025 dan diterjemahkan dalam Rencana Pembangunan Jangka Menengah Nasional (RPJMN) Tahun 2010-2014 menempatkan pembangunan pangan dan gizi menjadi prioritas pembangunan nasional dan memerlukan upaya lintas bidang. Selanjutnya, dalam Instruksi Presiden Nomor 3 Tahun 2010 tentang Program Pembangunan yang Berkeadilan yang terkait dengan Rencana Tindak Upaya Pencapaian Tujuan Pembangunan Milenium (MDGs) mengintruksikan kepada pusat dan seluruh provisni untuk menyusun Rencana Aksi Pangan dan Gizi 2011-2015. Sehingga artikel ini merupakan kajian teori tentang perilaku konsumsi pangan yang diuraikan sebagai berikut;

\section{TEORI PERILAKU}

Veithzal R. dan Deddy M. (2011) perilaku adalah semua yang dilakukan seseorang. Bentuk tingkah laku manusia adalah segala aktivitas, perbuatan, dan penamplan diri sepanjang hidupnya. Bentuk tingkah laku manusia adalah aktivitas individu dan realisasinya dengan lingkungan. Misalnya; perilaku seorang pekerja adalah kompleks, 
sebab dipengaruhi dari berbagai variabel lingkungan dan banyak faktor individual, pengalaman dan kejadian.

Selanjutnya Joyce B dkk (2011) rnengatakan bahwa perilaku diakui oleh hukum dan memiliki variabel-vaniabel lingkungan. Manusia memberikan respon pada beberapa variabel yang ada di lingkungannya dengan pengaruh counter conditioning Paksaan dari luar ini menstimulasi individu untuk melakukan atau menjauhi perilaku tertentu. Perilaku mempunyai kemungkinan akan dapat diperkuat atau diperlemah dan direspons yang muncul dan lingkungan. Dalam hal ini, counter conditioning juga berkaitan erat, meski kelihatannya berbeda, sebab counter conditioning mengharuskan adanya proses pembelajaran kembali. Dalam counter conditioning penilaku yang tidak sesuai dengan kondisi lingkungan akan berubah menjadi penilaku yang lebih sesuai dengan kondisi lingkungan dimana seseorang bertempat tinggal.

Lebih lanjut dikatakan bahwa perilaku secara esensial merupakan segala sesuatu yang dikerjakan oleh seseorang. Perilaku manusia pada hakikatnya berorientasi pada tujuan. Perilaku seseorang itu pada umumnya dirangsang oleh keinginan mencapai beberapa tujuan. Perilaku merupakan penampilan yang akan ditetapkan dalam suatu peristiwa yang berfungsi penguatan. Perilaku seseorang dapat dipelihara atau dipertahankan pada periode waktu yang cukup lama. Dengan demikian, perilaku pada dasarnya adalah perbuatan yang dapat diamati secara fisik pada diri seseorang.

Skinner (2013) mengatakan bahwa perilaku berkaitan dengan struktur individu, seperti; proporsi tubuh, bentuk dan kepala, warna dahi, mata, kulit, atau rambut, dan bentuk tubuh lain, yang dapat membentuk perilaku seseorang untuk berbuat atau mengerjakan sesuatu. Perilaku tersebut dapat dikatakan sebagai perilaku yang dibawah lahir karena berkaitan dengan bentuk dan struktur tubuh manusia. Dilain pihak perilaku masih memungkinkan untuk dipengaruhi oleh lingkungan dimana seseorang bertempat tinggal.

Selanjutnya Skinner (2013) mengatakan perilaku berkaitan dengan relasi sosial seseorang dan bagaimana pengaruhnya terhadap lingkungan. Perilaku dapat dibedakan menjadi: (a) perilaku yang alami (innate behavior), (b) perilaku operan (operant behavior). Perilaku alami yaitu perilaku yang dibawa sejak orang itu dilahirkan, yaltu berupa refleksrefleks dan insting-insting. Perilaku yang refleks merupakan perilaku yang terjadi secara spontan terhadap stimulus mengenai orang tersebut dan tidak dapat dikendalikan. Sedangkan perilaku operan yaitu perilaku yang dibentuk melalu.i proses belajar dari mempelajari. Perilaku operan ini dikendalikan dan diatur oleh pusat kesadaran atau otak.

Lebih lanjut Skinner (2013) juga mengatakan perilaku manusia sebagian besar adalah perilaku yang dapat dibentuk perilaku yang dipelajari dan dikembangkan. Berkaitan hal tersebut, perilaku manusia dapat dibentuk dengan cara: (1) pembentukan dengan conditioning atau kebiasaaan; (2) pembentukan dengan insight atau pengertian; dan (3) pembentukan dengan model.

Lebih lanjut Skinner (2013) menjelaskan bahwa perilaku sosial dapat didefinisikan sebagai perilaku dan dua atau lebih orang saling hormat mnghormati satu sama lain, atau dalam konsep lain respek terhadap lingkungan. Hal ini membantah bahwa terdapat perbedaan perilaku perorangan dan keadaan lingkungan yakni "keadaan sosial" dan "kekuatan sosial" yang tidak dapat dideskripsikan - bahasa dan ilmu pengetahuan alami. Salah satu disiplin khusus dinamakan "ilmu pengetahuan sosial" diperlukan karena mampu dan nyata dapat menerobos kelangsungan sifat alami. Terdapat berbagai faktor yang mempengaruhinya, yalali; concerning, peperangan, migrasi, kondisi ekonomi, dan praktek budaya, dengan demikian kita tidak pernah membayangkan diri sendiri untuk mempelajari kalau orang-orang berkumpul dan berkelompok, namun berkelakuan yang tidak sarna. Ketertarikan pada ilmu pengetahuan alam saat terlihat para ahli di tempat kerjanya, seperti fisika, ilmu kimia, dan biologi, dan saat itu perilaku teraplikasi pada bidang tersebut. 
Berapa banyak para ahli dapat berperilaku dari kelompok kerjanya. Banyak kesamaan pada taraf kebutuhan dari suatu kelompok, tetapi tidak pada tataran perilaku pada suatu kelompok. (Skinner, 2013)

Selanjutnya Robert E. Slavin (2006) mengatakan bahwa prinsip-prinsip dasar teori belajar tingkah laku adalah dibentuk dengan kukuh oleh apapun secara psikologi dan telah dilakukan dalam berbagai kondisi yang berbeda. Prinsip ini berguna untuk menjelaskan berbagai perilaku manusia karena perilaku manusia dapat berubah ke arah yang lebih baik bahkan lebih berguna.

Perilaku pada dasarnya berorientasi pada tujuan, dengan kata lain, perilaku kita pada umumnya dimotivasi oleh suatu keinginan untuk mencapai tujuan tertentu. Tujuan spesifik tersebut tidak selalu diketahui secara sadar oleh individu yang bersangkutan (Winardi, 2004).

Berikut merupakan definisi perilaku sebagai hasil dari konstruksi teori-teori dan riset, sebagai berikut: (1) Perilaku merupakan sesuatu yang disebabkan karena sesuatu hal, (2) Perilaku ditunjukan ke arah sasaran tertentu, (3) Perilaku yang dapat diobservasi dapat diukur, (4) Perilaku yang tidak langsung dapat di observasi (contoh berpikir, melaksanakan persepsi) juga penting dalam rangka mencapai tujuan-tujuan, dan (5) Perilaku dimotivasi.

Keyakinan terhadap perilaku atau behavioral belief yaitu hal-hal yang diyakini oleh individu mengenai sebuah perilaku dari segi positif dan negatif, sikap terhadap perilaku atau kecenderungan untuk berëaksi secara afektif terhadap suatu perilaku, dalam bentuk suka atau tidak suka pada peritaku tersebut. (Ajzen, 2005)

Keyakinan Normatif (Normative Beliefs), yang berkaitan langsung dengan pengaruli lingkungan yang secara tegas dikemukakan oleh Lewin dalam Field Theory. Pendapat Lewin ini digaris bawahi juga oleb Ajzen melalui Problem Behavior Theory (PBT). Ajzen (2005), faktor lingkungan sosial khususnya orang-orang yang berpengaruh bagi kehidupan individu (significant others) dapat mempengaruhi keputusan individu.

Norma subjektif (Subjective Norm) adalah sejauh mana seseorang memilild motivasi untuk mengikuti pandangan orang terhadap perilaku yang akan dilakukannya (Normative Belief). Kalau individu merasa itu adalah hak pribadinya untuk menentukan apa yang akan dia lakukan, bukan ditentukan oleh orang lain disekitarnya, maka dia akan méngabaikan pandangan orang tentang perilaku yang akan dilakukannya. Fishbein dan Ajzen (1975) menggunakan istilah positif pada perilaku tertentu, dan sejauh mana kalau dia menillih untuk melakukan perilaku tertentu itu dia mendapat dukungan dan orang-orang lain yang berpengaruh dalam kehidupannya

Beberapa Teori tentang perilaku lainnya, menyepakati bahwa: (i) perilaku adalah akibat, (ii) perilaku diarahkan oleh tujuan, (iii) perilaku yang dapat diamati dan diukur, (iv) perilaku yang tidak dapat secara langsung diamati, dan (v) perilaku dimotivasi/didorong.

Para behaviorisme tidak percaya bahwa manusia memiliki kehendak bebas, yang berarti; mereka tidak berpikir bahwa seseorang dapat seen bebas memilih untuk memunculkan perilaku tertentu. Melainkan, meraka percaya bahwa manusia merupakan bagian dan dunia alami, dan bahwa dunia alami adalah bagian dan kejadian-kejadian termasuk perilaku dan manusia itu sendiri telah ditentukan seen kausal.

\section{TEORI KONSUMSI}

Konsumsi berasal dari bahasa Belanda consumptie, ialah suatu kegiatan yang bertujuan mengurangi atau menghabiskan daya guna suatu benda, baik berupa barang maupun jasa, untuk memenuhi kebutuhan dan kepuasan secara langsung. Menurut Chaney (2003) konsumsi adalah seluruh tipe aktifitas sosial yang orang lakukan sehingga dapat di pakai untuk mencirikan dan mengenal mereka, selain (sebagai tambahan) apa yang mungkin mereka lakukan untuk hidup. Chaney menambahkan, gagasan bahwa konsumsi 
telah menjadi (atau sedang menjadi) fokus utama kehidupan sosial dan nilai-nilai kultural mendasari gagasan lebih umum dari budaya konsumen.

Menurut Braudrillard (2004), konsumsi adalah sistem yang menjalankan urutan tanda-tanda dan penyatuan kelompok. Jadi konsumsi itu sekaligus sebagai moral (sebuah sistemideologi) dan sistem komunikasi, struktur pertukaran. Dengan konsumsi sebagai moral, maka akan menjadi fungsi sosial yang memiliki organisasi yang terstruktur yang kemudian memaksa mereka mengikuti paksaan sosial yang tak disadari.

Ada dua kecenderungan seseorang dalam melakukan proses konsumsi, yitu : (1) Konsumsi Vertikal : orang melakukan konsumsi dengan menitikberatkan pada pemenuhan satu kebutuhan tertentu hingga mencapai tingkat kepuasaan yang tinggi, sedangkan kebutuhan yang lain kurang diperhatikan sehingga tingkat kepuasaannya rendah, dan (2) Konsumsi Horizontal : orang melakukan konsumsi dengan memperhatikan berbagai macam kebutuhannya, dan berusaha mencapai tingkat kepuasan yang mendekati sama dari berbagai macam pemenuhan kebutuhan tersebut.

Dari konsumsi yang bersifat vertical melahirkan Hukum Gossen I yang berbunyi : "Jika pemenuhan satu kebutuhan dilakukan secara terus menerus, tingkat kenikmatan atas pemenuhan itu semakin lama akan semakin berkurang hingga akirnya mencapai titik kepuasan tertentu“"

Contoh : ketika kita makan bakso, dari mangkok pertama kita bisa merasakan kenikmatan yang luar biasa, kemudian ketika kita tambah lagi maka kenikmatan yang akan kita peroleh akan berkurang, tapi ketika mangkok yang ketiga mungkin kita sudah tidak merasakan nikmat atau bahkan muntah karena terlalu kekenyangan. berbunyi :

Dari konsumsi yang bersifat horizontal melahirkan Hukum Gossen II yang "Pada dasarnya, manusia cenferung memenuhi berbagai macam kebutuhannya sampai pada tingkat intensitas / kepuasaan yang sama“

Contoh : dari uang saku kita yang sebesar Rp. 50.000,00 kita berusaha agar semua kebutuhan kita terpenuhi dengan baik (tingkat kepuasaan hampir sama), maka kita kemudian mulai mengalokasikan uang tersebut agar semua kebutuhan kita bisa tercukupi.

\section{TEORI PANGAN}

Pangan adalah segala sesuatu yang berasal dari sumber hayati dan air, baik yang diolah maupun yang tidak diolah, yang diperuntukkan sebagai makanan ataupun minuman bagi konsumsi manusia. Termasuk di dalamnya adalah bahan tambahan pangan, bahan baku pangan dan bahan lain yang digunakan dalam proses penyiapan, pengolahan atau pembuatan makanan atau minumam (Saparinto dan Hidayati, 2006).

Pangan adalah: (1) Setiap substansi yang dapat dimetabolisme oleh organisme untuk memberikan energi dan membangun jaringan; (2) Substansi yang padat (kebalikan cair) yang digunakan sebagai sumber dari makanan (makanan dan minuman); (3) Sesuatu yang memberikan rangsang mental untuk berfikir (Robinson dalam Handinsyah dan Martianto. 2001:3).

Pangan adalah segala sesuatu yang berasal dari sumber hayati produk pertanian, perkebunan, kehutanan, perikanan, peternakan, perairan, dan air, baik yang diolah maupun tidak diolah yang diperuntukkan sebagai makanan atau minuman bagi konsumsi manusia, termasuk bahan tambahan Pangan, bahan baku Pangan, dan bahan lainnya yang digunakan dalam proses penyiapan, pengolahan, dan/atau pembuatan makanan atau minuman (UU RI Nomor 18 Tahun 2012).

Berdasarkan cara perolehannya, pangan dapat dibedakan menjadi 3 (Saparinto dan Hidayati, 2006) :

a. Pangan segar 
Pangan segar adalah pangan yang belum mengalami pengolahan. Pangan segar dapat dikonsumsi langsung ataupun tidak langsung.

b. Pangan Olahan

Pangan olahan adalah makanan atau minuman hasil proses pengolahan dengan cara atau metode tertentu, dengan atau tanpa bahan tambahan. Contoh: teh manis, nasi, pisang goring, dan sebagainya.

Pangan olahan bisa dibedakan lagi menjadi pangan olahan siap saji dan tidak siap saji, yaitu: (1) Pangan olahan siap saji adalah makanan dan minuman yang sudah diolah dan siap disajikan di tempat usaha atau di luar tempat usaha atas dasar pesanan, (2) Pangan olahan tidak siap saji adalah makanan atau minuman yang sudah mengalami proses pengolahan, akan tetapi masih memerlukan tahapan pengolahan lanjutkan untuk dapat dimakan atau minuman, dan (3) Pangan Olahan Tertentu adalah pangan olahan yang diperuntukkan bagi kelompok tertentu dalam upaya memelihara dan meningkatkan kualitas kesehatan. Contoh: ekstrak tanaman stevia untuk penderita diabetes, susu rendah lemak untuk orang yang menjalani diet rendah lemak dan sebagainya

\section{KESIMPULAN}

Berdasarkan teori - teori yang telah disajikan, maka dapat disimpulkan bahwa:

Perilaku Konsumsi Pangan adalah pola-pola konsumsi terhadap ketersediaan pangan, daya beli terhadap pangan, pengetahuan, dan sikap terhadap yang berasal dari sumber hayati dan air, baik yang diolah maupun yang tidak diolah, yang diperuntukkan sebagai makanan ataupun minuman bagi konsumsi manusia.

\section{REFERENSI}

Joyce, B., Wheil, M., dan Calhoun, E. (2011), Models of Teaching (Model- Model Pengajaran) Edisi Kedelapan, Pustaka Pelajar, Yogyakarta.

Slavin, R.E. and Davis, N., 2006. Educational psychology: Theory and practice.

Skinner, B.F., 2013. Ilmu pengetahuan dan perilaku manusia. Diterjemahkan Maufur). Penerbit Pustaka Pelajar. Yogyakarta.

Veithzal dan Mulyadi, Deddy. 2011. Kepemimpinan dan Perilaku Organisasi. Jakarta: PT Raja Grafindo Persada.

Winardi, A., 2004. Teori Perilaku Birokrasi. Jakarta: Penerbit Balai Pustaka. 